\title{
Comparación del postoperatorio de dos colgajos en cirugía de terceros molares inferiores
}

\author{
Post operative comparison of two flap designs in lower third molar surgery
}

\author{
G. Laissle Casas del Valle', P. Aparicio Molares', F. Uribe Fenner', D. Alcocer Carvajal2
}

\begin{abstract}
Resumen: La cirugía de terceros molares constituye en la práctica de la cirugía oral y maxilofacial, una de las intervenciones más realizadas. Las indicaciones son variadas, desde medidas profilácticas hasta grandes lesiones osteolíticas. Algunas de las consecuencias después de dicha intervención son; edema, trismus y dolor postoperatorio. En la técnica quirúrgica, el colgajo cobra gran importancia a la hora de minimizar estas consecuencias. El objetivo del presente estudio es evaluar el postoperatorio de la cirugía de terceros molares mandibulares incluidos, utilizando un colgajo lineal en un lado y un colgajo triangular en el otro lado del mismo paciente.

Se realizó un estudio prospectivo en 15 pacientes de la Facultad de Odontología de la Universidad Mayor. Se tomaron registros fotográficos estandarizados y se midió la apertura bucal máxima pre-quirúrgica de cada paciente. Se registró el edema, la limitación de apertura bucal y el dolor a las 48 horas y a los 7 días, además del tiempo intraoperatorio. Todos los datos fueron analizados estadísticamente. No existen diferencias significativas en el edema, limitación de la apertura ni dolor al utilizar ambos colgajos. Tampoco existe correlación entre el tiempo operatorio y las tres variables estudiadas.

El postoperatorio de la cirugía de terceros molares mandibulares incluidos es similar al utilizar un colgajo lineal o un colgajo triangular. El cirujano puede optar por uno o el otro indistintamente, según su preferencia.
\end{abstract}

Palabras clave: Terceros molares; Colgajo lineal; Colgajo triangular; Edema; Trismus; Dolor.

Recibido: 13.02.2008

Aceptado: 28.05 .2009

\begin{abstract}
One of the most common procedures in the field of Oral and Maxillofacial Surgery is third molar surgery. From prophylactic measures to large osteolytic lesions, there are various indications. Some of the consequences of this procedure are; edema, trismus and postoperative pain. Flap design is an important feature of surgical technique that plays a vital role in minimizing these consequences. The objective of this study is a post operative evaluation of included third molar jaw surgery using a linear flap on one side and a triangular flap on the other side of the same patient.

A prospective study of 15 patients from the Dentistry College at the Major University was carried out. Before surgery standard photos were taken and maximum oral opening was measured for each patient. The edema, maximum oral opening and pain were measured 48 hours and 7 days after surgery. All of the data were analyzed statistically. There are no significant differences in the edema, ability to open the mouth or the level of pain using the two types of flap. There also is no correlation between the operation time and the three variables studied.

The postoperative edema, pain and trismus after included third molar surgery are similar when using linear or triangular flap designs. The surgeon can choose one or the other indistinctly, according to his/her preference.
\end{abstract}

Key words: Third Molars; Linear Flap; Triangular Flap; Edema; Trismus; Pain.
1 Cirujano Dentista

2 Cirujano Maxilofacial

Facultad de Odontología Universidad Mayor. Cátedra de Cirugía y Traumatología.

Santiago, Chile

\section{Correspondencia:}

Germán Laissle Casas del Valle

La Castellana Norte 100, Departamento 132

Bucomáxilofacial. Santiago, Chile

Email: fran.uribe@gmail.com 


\section{Introducción}

La cirugía de terceros molares constituye en la práctica de la cirugía oral y maxilofacial una de las intervenciones más realizadas, por lo cual ha sido un tema ampliamente documentado a través de la historia. ${ }^{1-4}$ Las indicaciones para la cirugía de estos molares son variadas, desde medidas profilácticas hasta pacientes que presentan grandes lesiones osteolíticas en relación a terceros molares, principalmente mandibulares. 1,3,4,6 Como en toda cirugía existen también complicaciones que van desde episodios hemorrágicos postquirúrgicos, de fácil manejo, hasta a veces grandes infecciones maxilofaciales que requieren tratamientos más complejos. 2,3,5,6 Es por esto que se han buscado múltiples formas de disminuir estas complicaciones, ya sea mejorando las medidas de asepsia; usando antibióticos o utilizando distintas maniobras y procedimientos en la técnica quirúrgica propiamente tal. $3,4,7-12$

Algunas características del postoperatorio son el edema, provocado principalmente por la osteotomía que se realiza; la limitación de apertura bucal (trismus) y el dolor postoperatorio. En la técnica quirúrgica el colgajo cobra gran importancia a la hora de minimizar estas consecuencias. $7,8,10$ Se han publicado algunos estudios que comparan el postoperatorio y la cicatrización utilizando distintos diseños de colgajo.7,8,10,12

El objetivo de este estudio fue evaluar el postoperatorio de la cirugía de terceros molares mandibulares incluidos, en pacientes con indicación de exodoncia de ambos molares, utilizando dos diseños de colgajo diferentes en el mismo paciente, uno a cada lado.

\section{Material y método}

En este estudio clínico prospectivo, se realizó una evaluación y posterior comparación de dos diseños de colgajo para la cirugía de terceros molares mandibulares incluidos, en pacientes que acudieron a la Clínica de Cirugía Oral de la Universidad Mayor y al Servicio de Cirugía de la Central Odontológica del Ejército (COE) durante los meses de Julio y Septiembre de 2004. Se incluyeron sólo pacientes ASA I, y con ambos terceros molares mandibulares incluidos, en una posición simétrica (no más de 15 grados de diferencia) y asintomáticos. Se excluyeron de este estudio pacientes con patologías locales como pericoronaritis o abscesos.

El grupo de estudio comprendió un total de 15 pacientes. La posición de cada molar se determinó radiográficamente y se clasificó según Pell y Gregory.

Se tomó además una fotografía clínica de rostro frontal, con una cámara digital Nikon Coolpix 4500, la cual se encontraba fija a un cefalostato, fabricado para este propósito, con el cual se individualizó la posición de cada paciente, para ser reproducida posteriormente en las fotografías postoperatorias (Fig. 1).

También se midió la apertura bucal máxima pasiva (lo máximo que pueda abrir la boca el paciente por si solo), mediante el uso de un pie de metro manual (marca Mauser). Esta medición se realizó entre los bordes incisales de las piezas dentarias 1,1 y 4,1, haciendo tres mediciones y sacando un promedio. Este valor en milímetros se traspasó a porcentaje de limitación de apertura bucal.

\section{Introduction}

The third molar is one of the most practiced surgeries in the Oral and Maxillofacial Surgical field. As a consequence this topic has been thoroughly documented throughout history..$^{1-4}$ The indications for surgery range from prophylactic measures, to patients that present large osteolytic lesions related to third molars, mainly mandibular. 1,3,4,6 Like all surgeries, there are complications. These include everything from episodes of post surgical hemorrhage to, in some cases, large maxillofacial infections that require more complex treatments. $23,3,6$ As a result multiple forms of reducing these complications have been researched. Whether it be the improving the measures of asepsis, the use of antibiotics, or the use distinct technical maneuvers and procedures in the actual surgical technique. 3, 4, 7-12

Some of the postoperative characteristics looked at in patients are edema (initiated mainly because of the osteotomy that is carried out), maximum mouth opening (trismus) and postoperative pain. The flap design plays an important role in surgical technique in terms of minimizing these consequences. $7,8,10$ Studies have been published that compare scarring and postoperative status when using distinct flap designs. $7,8,10,12$

The objective of this study was postoperative evaluation of Impacted Third Molar surgery, in patients with signs of exodontia in both molars, using two different flap designs (one on each side) on the same patient.

\section{Materials and method}

In this prospective clinical study the two flap designs used in Impacted Third Molar surgery were evaluated and later compared. The patients studied attended the Oral Surgery Clinic at the Universidad Mayor and the Spanish Army's Central Odontological Surgery Center for two months in July and September of 2004. They included only ASA I patients who had both mandible third molars in symmetrical positions (no more that 15 degrees of difference) and who were A-symptomatic. Patients with local pathologies such as pericoronaritis or abscesses were excluded from the study.

The study group consisted of 15 patients. The position of each molar was determined radio graphically and classified according to Pell and Gregory.

A clinical photo was taken of the front of the face using a Nikon Coolpix 4500 digital camera. This picture was then attached to a cephaloslate, made for this purpose, which was later used to determine the condition of each patient. After surgery an identical picture would be taken and compared to the original (Fig. 1).

The maximum mouth opening was also measured (the maximum amount the patient could open their mouth by themselves) with a ruler (Mauser brand). This measurement was taken between the edges of the incisions of teeth 1.1 
El equipo de trabajo estuvo compuesto por dos operadores y un investigador, quien hizo las mediciones y tomó las fotografías pre y postoperatorias (48 horas y 7 días).

\section{Protocolo quirúrgico}

Se realizaron dos cirugías en cada paciente con un intervalo de dos semanas. En la primera cirugía se intervino la pieza 3.8 utilizando en todos los casos el colgajo lineal. La desinclusión de la pieza 4.8 se realizó en una segunda cirugía, utilizando un colgajo triangular. Ambas intervenciones estaban previamente protocolizadas. Se utilizaron los siguientes fármacos; Amoxicilina $2 \mathrm{~g}$, 1 hora antes, Betametasona $3 \mathrm{mg}, 1$ hora antes y 1,5 mg, 6 horas después, e lbuprofeno $400 \mathrm{mg}, 1$ hora antes $y$ continuar $400 \mathrm{mg}$, cada 8 horas por 3 días. En caso de presentar hipersensibilidad a la penicilina se administró Clindamicina $600 \mathrm{mg}, 1$ hora antes.

Ambas intervenciones fueron realizadas bajo anestesia local con vasoconstrictor. El colgajo traingular consiste en una incisión que comienza recorriendo la rama ascendente mandibular hasta llegar a distovestibular del segundo molar, desde ahí se practica una incisión que va hacia adelante y abajo en $45^{\circ}$, formando un triángulo. Ofrece una óptima visibilidad, no daña periodontalmente a los dientes vecinos, ya que no recorre el surco dentario, permite una buena reposición del colgajo, lo que mejora la cicatrización del sitio quirúrgico (Fig. 2). ${ }^{7} \mathrm{El}$ colgajo linear en cambio consiste en una incisión que comienza recorriendo la rama ascendente mandibular hasta llegar a la zona distovestibular del segundo molar, pasando por el centro del tercer molar que se encuentra retenido. Desde ahí se extiende con una incisión surcular hasta distal del primer molar la mayoría de las veces. Se caracteriza por permitir una adecuada visibilidad. Es apropiado para inclinaciones mesiales y terceros molares superficiales (Fig. 3). ${ }^{3}$

Una vez determinado el colgajo a utilizar se realizó la incisión, levantamiento del colgajo, la osteotomía y/o odontosección necesaria, todo bajo irrigación con suero fisiológico. La luxación y la exodoncia del tercer molar se realizaron con elevadores y/o luxadores. Se retiró el saco pericoronario, y se eliminaron todas irregularidades óseas. Al re-posicionar el colgajo se suturó con seda $3 / 0$. Se dieron las indicaciones postoperatorias al paciente en forma verbal y escrita.

Durante la cirugía se tomó el tiempo intraoperatorio entre el inicio de la incisión y el último punto de sutura.

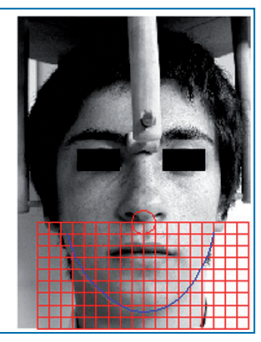

and 4.1, using the mean of three measurements. This value was converted from millimeters into the percentage of maximum mouth opening. The team of researchers consisted of two operators and one investigator, who took the measurements and photographs before and after surgery (48 hours and 7 days).

\section{Surgical Protocol}

Two surgeries were performed at an interval of 2 weeks on each patient. During the first surgery tooth 3.8 was operated on was using the linear flap design. During the second surgery the tooth 4.8 was removed using the triangular flap design. Both operations were part of the previous protocol. The following medications were used: Amoxicillin 2 g 1 hour before, Betametasone $3 \mathrm{mg} 1$ hour before and $1.5 \mathrm{mg} 6$ hours after, and Ibuprofen $400 \mathrm{mg}, 1$ hour before and every 8 hours for 3 days. Clindamycin $600 \mathrm{mg}$ was administered 1 hour before in patients who were allergic to Penicillin.

Both extractions were administered under local anesthetic with vasoconstrictor. The triangular flap consists of one incision that starts along the ramus rising up the mandible to the distal vestibular of the second molar, from there an incision is made going forward and down 45 degrees, forming a triangle. This offers maximum visibility and does not harm neighboring teeth. Since it doesn't go over the dental groove, it allows for good reposition of the flap which improves scarring of the surgical site (Fig. 2). Contrarily, the linear flap consists of an incision that starts running along the ramus rising up the mandible until the distal vestibular of the second molar, passing over the center of the kept third molar. From there it is extended with a circular incision until, in most cases, the distal of the first molar. This allows for proper visibility and is suitable for sloped mesials and surfaced third molars 3 (Fig. 3).

Once a flap design has been decided the incision is made, necessary osteotomy and-or tooth section, irrigating with physiological serum. The luxation and exodontia of the third molar are carried out with elevators and luxators. The peri- 


\section{Mediciones postoperatorias}

Los controles se realizaron a las 48 horas y al séptimo día. En los controles se midió la apertura bucal y dolor postoperatorio. El dolor se midió utilizando el método EVA (escala visual análoga) en el cual al paciente se le entregó una hoja con una línea recta numerada del 0 al 10, con las leyendas "Sin Dolor" y "Dolor Insoportable" en sus extremos. Se le preguntó al paciente cuanto le dolía en ese momento.

Además se tomó una segunda foto clínica utilizando el cefalostato para la posterior evaluación computacional del edema.

También se evaluó clínicamente la presencia de complicaciones (alveolitis, infección, hemorragia).

\section{Medición del edema postoperatorio}

Se compararon fotografías pre y postoperatorias de cada paciente, tomadas utilizando un cefalostato con tres puntos cefalométricos como sitios de apoyo (ambos conductos auditivos externos y Nasion). Las tres fotografías clínicas (preoperatoria, 48 horas y 7 días), fueron convertidas a blanco y negro utilizando el software Adobe Photoshop 8.0 para obtener un mejor contraste del perímetro facial. El análisis de las fotografías se realizó en el software Autocad 2004 marcando el contorno facial desde un lóbulo de la oreja al otro. Se construyó una grilla utilizando como centro el punto subnasal para medir los perímetros. Los datos obtenidos fueron traspasaron a porcentaje para su posterior análisis estadístico utilizando el software Systat 11.

\section{Resultados}

En el análisis estadístico se utilizó el Test t para las variables de edema, limitación de apertura bucal y dolor. Para observar si había relación entre el tiempo operatorio y las otras variables ya mencionadas, se utilizó la Correlación de Pearson.

Las edades fluctuaron entre los 16 y 24 años, con un promedio de 18,93 años. El sexo predominante fue el masculino con un $60 \%$. Aplicando la clasificación de Pell y Gregory, la posición clase 2 fue la más prevalente con un $70 \%$. A su vez la relación clase B se observó mayoritariamente con un $53,33 \%$. La angulación de los terceros molares más frecuente fue la mesial con un $93,33 \%$.

Los resultados entregados por el análisis estadístico, entre el colgajo lineal y el colgajo triangular para el edema fue de $p=0,078$ a las 48 horas y $p=0,803$ a los 7 días. Esto demuestra que no existe diferencia significativa $(p<0,05)$ en el edema entre los dos colgajos (Fig. 4).

Para la limitación de apertura bucal postquirúrgica, los resultados fueron $p=0,172$ a las 48 horas y $p=0,102$ a los 7 días. Esto muestra que tampoco existe diferencia estadísticamente significa- coronary sack is removed and irregular boney spicles removed. When repositioning the flap it is sutured with $3 / 0$ silk. Post surgical instructions were given to the patient verbally and in writing.

The surgery was timed from the point of the initial incision until the last stitch was made.

\section{Post-operative}

Measurements

Measurements were taken 48 hours and 7 days after surgery. These measurements include the maximum mouth opening and post operative pain. The pain is measured using the EVA method (visual scale method) in which the patient is given a sheet with a straight line numbered 1-10 with the legends "No pain" and "Unbearable Pain" on each side. The patient was asked how much pain they were in at that time.

In order to calculate the post operative edema a second photograph was taken using cephalostate.

The presence of certain complications was also clinically evaluated. These complications include alveolitis, infection, hemorrhaging.

\section{Measurement of Postoperative Edema}

Pre and post surgery photographs were compared for each patient, taken using a cephalostat with 3 cephalometric points as reference points (both external auditive conducts and Nasion) The three clinical photographs (pre operation, 48 hours after and 7 days after) were converted into black and white using Adobe Photoshop 8.0 in order to get better contrast of the facial perimeter. The photographs were analyzed using AutoCAD 2004 software marking the contour of the face from one earlobe to the other. It created a grid that used the nose as a center point to measure the perimeters. Then using Systat 11 software, the data obtained were converted into a percentage for posterior statistical analysis.

\section{Results}

Test $t$ was used in the statistical analysis for the variables of edema, maximum mouth opening and pain. Pearson Correlation was used in order to determine if there was a relationship between operation time and the other variables already mentioned.

Patient age ranged from 16 to 24 , with an average age of 18.93. At $60 \%$ the predominant sex was male. Applying 
tiva entre ambos colgajos para esta variable (Fig. 5).

Para realizar la medición de dolor se utilizó la escala visual análoga (EVA), a las 48 horas el valor $p=0,334$ y a los 7 días $p=0,173$. Para ambas variables tampoco existe diferencia significativa entre ambos colgajos (Fig. 6).

A continuación en la tabla 1 se muestran el número de casos de alveolitis e infección y la incidencia que tuvieron en relación a todos los molares extraídos. Se observa un bajo porcentaje de estas complicaciones, el caso de alveolitis ocurrió donde se realizó un colgajo triangular, mientras que la infección en un colgajo lineal.

No existe correlación entre el tiempo operatorio y el edema que presentaron ambos colgajos a las 48 horas y a los 7 días.

\section{Discusión}

No existen muchos estudios que evalúen el postoperatorio del diseño del colgajo, la mayoría analiza el uso de distintos fármacos, ${ }^{13,14}$ o evalúan la cicatrización periodontal del segundo molar después de la cirugía. $8,10,11$

Nuestro estudio reveló que no existen diferencias significativas entre el diseño del colgajo y el edema, limitación de apertura bucal y dolor postoperatorio. Resultados similares obtuvieron SuarezCunqueiro y cols., 12 quienes compararon el colgajo marginal (bayoneta) $\mathrm{v} / \mathrm{s}$ el colgajo paramarginal en la cirugía de terceros molares impactados encontrando que no existían diferencias significativas en el edema, limitación de apertura bucal y dolor postoperatorio. Concluyeron en que se puede utilizar indistintamente uno o el otro colgajo.

Según Jakse y cols. ${ }^{7}$ el diseño del colgajo influye considerablemente en la cicatrización primaria de la herida. El colgajo triangular, en forma significativa presentó menor porcentaje de dehiscencia. Aunque el objetivo de nuestro estudio no fue evaluar la cicatrización, coincidimos con este hallazgo. En cuanto al edema, dolor y limitación de apertura bucal, Jakse y cols. ${ }^{7}$ no encontraron diferencias entre ambos colgajos.

El edema postoperatorio se relaciona principalmente con la cantidad de trauma directo que ocurre sobre los tejidos durante la desinclusión. El porcentaje de edema de este estudio fue de alrededor del $1 \%$ para ambos colgajos, lo cual es bastante bajo en compa-
EDEMA \%

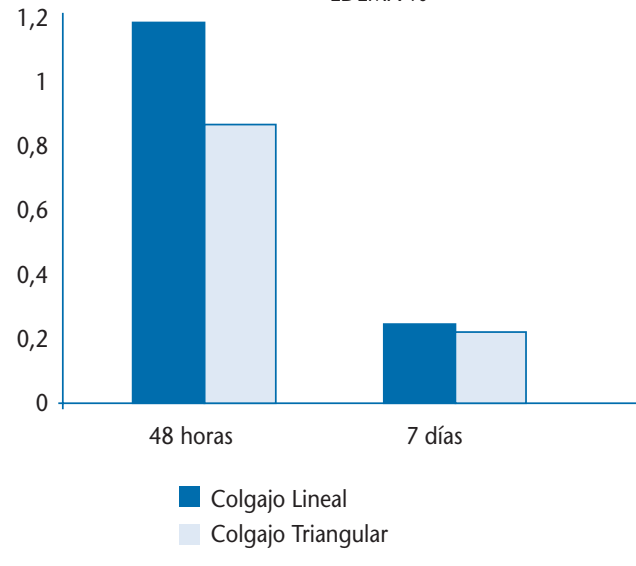

Fura 4. Comparación porcentual del edema entre ambos colgajos a las 48 horas y a los 7 días.

Figure 4. Percentage comparison of the swelling in the two flap designs 48 and 7 days after surgery.

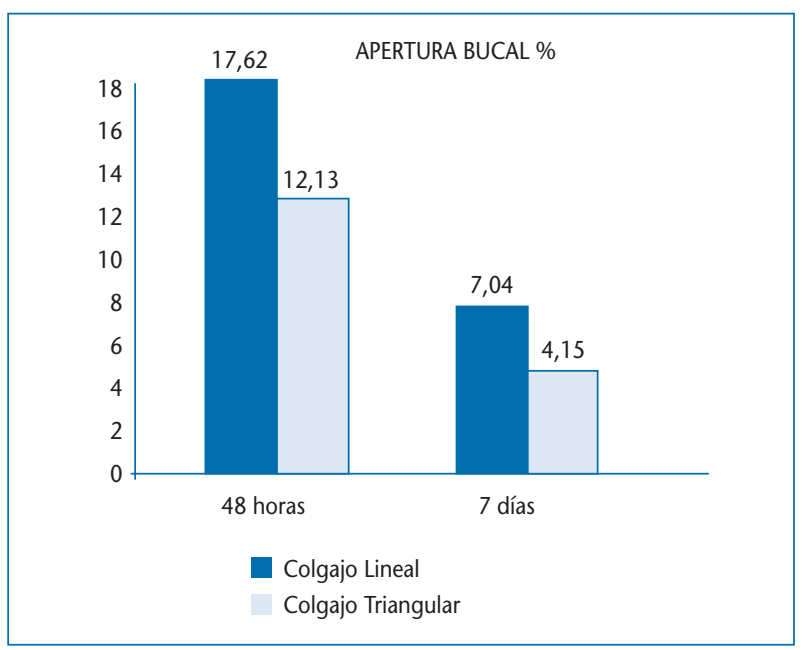

Figura 5. Comparación porcentual de limitación de apertura bucal entre ambos colgajos a las 48 horas y a los 7 días.

Figure 5. Percentage comparison of maximum mouth opening in the two flap designs 48 hours and 7 days after surgery. the Pell and Gregory Classification, the class 2 position was the most prevalent at $70 \%$. In turn, class B was observed in most cases with $53.33 \%$. The most frequent angle of the third molars was the mesial which occurred in $93.33 \%$ of cases. The results delivered by the statistical analysis, between the linear flap design and the triangular flap design were $p=0.078$ after 48 hours and $p=0.803$ after 7 days. This demonstrates that, in terms of edema there is no significant difference between the two flap designs (Fig. 4).

For maximum mouth opening post surgery, the results were $p=0.172$ after 48 hours and $p=0.102$ after 7 days. This demonstrates that for this variable there is also no significant statistical difference between flap designs (Fig. 5).

The Visual Scale Method (EVA) was to measure pain, 48 hours after surgery $p=$ 0.334 and 7 days after $p=$ 0.173 . For this variable there were no significant differences between the two flap designs (Fig. 6).

Table 1 shows the number of cases of alveolitis and infection, and their incidence in relation to all of the extracted molars. A low percentage of these complications are observed. Alveolitis occurred where the triangular flap design was used while infection occurred when the linear flap design was used.

There is no correlation between the operation time and edema in either design after 48 hours and 7 days.

\section{Discussion}

There are not many studies that perform post operative evaluations of flap design. The majority of the studies that exist analyze specific medications ${ }^{13,14}$ or evaluate post surgical second molar periodontal scarring.8,10,11 
ración con otros etudios. Esto puede deberse a la medicación, principalmente el uso de Betametasona oral en el pre y postoperatorio. Schultze-Mosgau y cols. ${ }^{15}$ señalan que el uso de Metilprednisolona en combinación con lbuprofeno otorga una buena acción antiinfamatoria y analgésica, previniendo el edema postoperatorio. Aunque la medición de edema con fotografías es bastante más exacto que otros métodos descritos en la literatura, el uso de cámaras 3D,16 objetivizan mucho más estas mediciones.

Se podría considerar que a mayor tiempo operatorio, existe un mayor trauma sobre los tejidos y por lo tanto más edema. Sin embargo, nosotros concluimos que no existe correlación entre ambas variables. El edema se relacionaría más bien con la dificultad de la cirugía que con el tiempo según lo confirma García y cols. ${ }^{17}$

Con respecto a la limitación de apertura bucal no obtuvimos una diferencia significativa entre ambos colgajos. Sí confirmamos que para los dos colgajos el peak de limitación de apertura bucal ocurrió a las 48 horas. También observamos que para ambos grupos mientras mayor limitación de apertura bucal a las 48 horas mayor limitación de apertura existió a los 7 días.

Suarez-Cunqueira y cols. ${ }^{12}$ determinaron que no existía diferencia en cuanto a la limitación de apertura bucal al utilizar dos colgajos diferentes. Ellos midieron esta variable a los 5 y 10 días, y a los 3 meses postquirúrgicos. En nuestro estudio no se correlaciona el tiempo operatorio con la limitación de apertura bucal, lo que confirmaría que esta variable depende más de la magnitud del dolor que presenta el paciente, por un efecto antiálgico.

Existen varios estudios que analizan la presencia de dolor y la intensidad de éste luego de la cirugía, pero son muy pocos los que comparan el diseño del colgajo con el dolor postoperatorio.

Suarez-Cunqueiro y cols. ${ }^{12}$ señalan que no existe relación entre el colgajo utilizado y la intensidad del dolor. En este estudio alcanzamos valores muy bajos de dolor postoperatorio, lo que podría explicarse por el uso de un protocolo farmacológico pre y postoperatorio en base a antibióticos, corticoides y antiinflamatorios no esteroidales. Según otros reportes, ${ }^{18}$ la presencia de dolor al igual que el edema y la limitación de la apertura bucal estarían más relacionadas con el trauma quirúrgico que con el diseño de colgajo utilizado.

La infección y la alveolitis son complicaciones que podemos encontrar luego de una intervención de este tipo. En nuestro estu-
DOLOR (EVA)

\section{7 días}

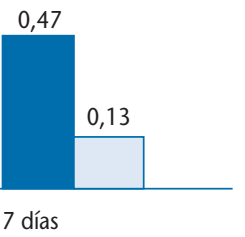

lgajo Lineal

Colgajo Triangular

Figura 6. Promedio de dolor (EVA) en ambos colgajos a las 48 horas y a los 7 días.

Figure 6. Average pain level in the two flap designs 48 hours and 7 days after surgery.

Tabla 1. Número de casos de incidencia de alveolitis e infección

$\begin{array}{lcc}\text { Number of Cases } & 1 & 1 \\ \text { Incidence } & 3,33 \% & 3,33 \%\end{array}$

Our study revealed that there are no significant differences between flap design and edema, mouth opening or post operative pain. SuarezCunqueiro et al. ${ }^{12}$ found similar results when they compared the marginal flap and the para-marginal flap in impacted third molars. They found that there were no significant differences between edema, mouth opening or post operative pain. They concluded that either design can be used interchangeably. According to Jakse et al.? the flap design considerably influences the first stages of scarring. The triangular flap resulted in a lower percentage of dehisency. Although the objective of our study wasn't to evaluate scarring, we agree with this finding. With regard to edema, pain and maximum mouth opening, Jakse et al.' did not find differences between the two flap designs.

Post operative pain is mainly related to the amount of direct trauma to the tissue during extraction. The percentage of edema in this study was about $1 \%$ in both flap designs. This is fairly low when compared to other studies. This could be the result of medication, mainly the use of oral Beta metasona before and after surgery. Shultze-Mosgau et al., ${ }^{15}$ point out that the use of metilprednisolone and Ibuprophen together works as a good anti-inflammatory and analgesic, preventing post operative edema. Although the measurement of edema with photographs is much more exact than the other methods described in the literature, the use of $3 D^{16}$ cameras makes these measurements more credible.

It might be considered that longer operation time would mean more traumas on the tissue and therefore more edema. However, we have concluded that there is no correlation between these variables. According to García et al., ${ }^{17}$ edema is more closely related to the difficulty of the surgery than to the time the surgery takes.

In reference to the mouth opening we didn't find any significant difference between the two flap designs. We confirm that for the two flap designs the peak of maximum mouth opening was measured after 48 hours. We also observed that for both groups when a patient experienced 
dio solo obtuvimos una infección que correspondió a un absceso vestibular donde se realizó un colgajo lineal, y un caso de alveolitis húmeda, en un paciente donde se utilizó el colgajo triangular. Si bien el número de pacientes de nuestro estudio es bajo, la prevalencia de estas complicaciones se relaciona con lo reportado en la literatura. ${ }^{19,20}$

Podemos concluir que el diseño del colgajo no tiene relación con el postoperatorio del paciente, y éste está determinado por otras condiciones, ya sean propias del paciente ${ }^{16}$ o de la intervención quirúrgica propiamente tal.

\section{Conclusiones}

El postoperatorio de la cirugía de terceros molares mandibulares incluidos, considerando edema, dolor y apertura bucal, es similar al utilizar un colgajo lineal o un colgajo triangular. El cirujano puede optar por uno o el otro indistintamente, según su preferencia.

\section{Bibliografía}

1. Asanami S, Kasazaki Y. Extracción del tercer molar, tipos y técnica. España; Ed. Doyma 1992;5.

2. Chiapasco M, De Cicco L, Marrone G. Side effects and complications associated with third molar surgery. Oral Surg Oral Med Oral Pathol 1993;76:412-20.

3. Donado M. Cirugía Bucal, patología y técnica. $2^{\text {a }}$ edición. Barcelona: Ed. Masson 2001.

4. Lytle JJ. Etiology and indications for the management of impacted teeth. Northwest Dent 1995;74:23-32.

5. Benediktsdottir IS, Wenzel A, Petersen JK, Hintze H. Mandibular third molar removal: risk indicators for extended operation time, postoperative pain, and complications. Oral Surg Oral Med Oral Pathol Oral Radiol Endod 2004;97:43846.

6. Gantz A, Cifuentes J, Figueroa L, Daniels R. Complicaciones en Cirugía de Terceros Molares. Análisis de 59 Consultas en Servicio de Urgencia Máxilo Facial. Revista Dental de Chile 2000;91:3-6.

7. Jakse N, Bankaoglu V, Wimmer G, Eskici A, Pertl C. Primary wound healing after lower third molar surgery: Evaluation of 2 different flap designs. Oral Surg Oral Med Oral Pathol Oral Radiol Endod 2002;93:7-12.

8. Motamedi MH. A technique to manage gingival complications of third molar surgery. Oral Surg Oral Med Oral Pathol Oral Radiol Endod 2000;90:140143.

9. Nagesbwar. Comma incision for impacted mandibular third molars. J Oral Maxillofac Surg 2002;60:1506-9.

10. Peng KY, Tseng YC, Shen EC, Chiu SC, Fu E, Huang YW. Mandibular second molar periodontal status after third molar extraction. J Periodontol 2001;72: 1647-51.

11. Rosa AL, Carneiro MG, Lavrador MA, Novaes AB. Influence of flap design on periodontal healing of second molars after extraction of impacted mandibular third molars. Oral Surg Oral Med Oral Pathol Oral Radiol Endod 2002;93:4047.

12. Suarez-Cunqueiro MM, Gutwald R, Reichman J, Otero-Cepeda XL, Schmelzeisen R. Marginal flap versus paramarginal flap in impacted third molar surgery: more maximum oral opening after 48 hours they also experienced a more maximum opening after 7 days.

Suarez-Cunqueria et al. ${ }^{12}$ determined that there were no differences in terms of mouth opening when using the two flap designs. They measured this variable 5 days, 10 days and 3 months after surgery. In our study there is no correlation between operation time and mouth opening, which would confirm that because of an antialgical effect this variable depends more on the magnitude of pain experienced by the patient.

There are various studies analyzing the presence of pain and its intensity after surgery but there are very few studies that compare flap design and post operative pain. SuarezCunqueiro et al..$^{12}$ show that there is no relation between the flap design used and the intensity of pain experienced. In this study reports of post operative pain were low, which could be explained by the use of pharmacological protocol pre and post operation with a base of antibiotics, corticoids and non-steroid anti-inflammatories. According to other reports the presence of pain is equal to edema and mouth opening is more closely related to surgical trauma than to the flap design used. The infection and alveolitis are complications that are found after surgeries of this type. In our there was only one case of infection related to a vestibular abscess located near the linear flap. Another patient had wet alveolitis when the triangular flap was used. The number of patients in our study is low, however the presence of these complications corresponds with the literature. 19,20

We can conclude that the flap design is not related to post operative status of the patient, but is rather determined by other factors be they specific to the patient or the actual surgery itself.

\section{Conclusions}

The post operative status of the patient after included third molar surgery which includes: edema, pain and mouth opening are similar when using either a linear or triangular flap design. The surgeon can choose one or the other according to his/her preference. 
a prospective study. Oral Surg Oral Med Oral Pathol Oral Radiol Endod 2003;95:403-8.

13. Piecuch JF, Arzadon J, Lieblich SE. Prophylactic antibiotics for third molar surgery: a supportive opinion. J Oral Maxillofac Surg 1995;53:53-60.

14. Poeschl PW, Eckel D, Poeschl E. Postoperative prophylactic antibiotic treatment in third molar surgery - a necessity? J Oral Maxillofac Surg 2004;62:3-8

15. Schultze-Mosgau S, Schmelzeisen R, Frolich JC, Schmele H. Use of ibuprofen and methylprednisolone for the prevention of pain and sweIling after removal of impacted third molars. J Oral Maxillofac Surg 1995;53:2-7

16. Yuasa $H$, Sugiura M. Clinical postoperative findings after removal of impacted mandibular third molars: prediction of postoperative facial swelling and pain based on preoperative variables. Br J Oral Maxillofac Surg 2004;42:209-14.

17. Garcia Garcia A, Gude Sampedro F, Gandara Rey J, Gallas Torreira M. Trismus and pain after removal of impacted lower third molars. J Oral Maxillofac Surg 1997; 55:1223-6.

18. White RP Jr, Shugars DA, Shafer DM, Laskin DM, Buckley MJ, Phillips C. Recovery after third molar surgery: clinical and health-related quality of life outcomes. J Oral Maxillofac Surg 2003;61:535-44.

19. Bloomer CR. Alveolar osteitis prevention by immediate placement of medicated packing. Oral Surg Oral Med Oral Pathol Oral Radiol Endod 2000;90:282-4.

20. Malagón-Londoño G, Malagón OM. Urgencias odontológicas. $3^{\text {a }}$ edición. Bogotá; Ed. Médica Panamericana; 2003. 